\title{
Political Attention in a Coalition System: Analysing Queen's Speeches in the Netherlands 1945-2007
}

Gerard Breeman $^{\mathrm{a}}$, David Lowery ${ }^{\mathrm{b}}$, Caelesta Poppelaars ${ }^{\mathrm{b}}$, Sandra L. Resodihardjo ${ }^{\mathrm{b}}$, Arco Timmermans ${ }^{\mathrm{b}}$ and Jouke de Vries ${ }^{\mathrm{b}}$

${ }^{a}$ Wageningen University, P.O. Box 8130, 6700 EW Wageningen, The Netherlands.

E-mail: Gerard.Breeman@wur.nl

${ }^{b}$ Leiden University, P.O. Box 9555, 2300 RB Leiden, The Netherlands.

E-mails: DLowery@fsw.leidenuniv.nl, CPoppelaars@fsw.leidenuniv.nl, Reso@fsw.leidenuniv.nl, ATimmermans@fsw.leidenuniv.nl,info@campusdenhaag.nl

At the beginning of each Parliamentary session, the Dutch Queen gives a speech (Troonrede) in which she presents the government's policy goals and legislative agenda for the year to come. The general assumption is that newly elected governments will use agenda-setting moments such as the Queen's speech to put new issues on the national agenda. But does this really happen? Are governmental agendas characterized by sudden shifts following elections or by continuity? After all, at least one coalition party of the previous Dutch government is also a member of the new coalition government. So how much do changes in coalition membership result in changes in policy agendas? In this paper, we study the macro-level structure of the Dutch policy agenda and link patterns of agenda-setting with the institutional context in which this agenda-setting process occurs, that is, the Dutch parliamentary democracy characterized by multi-party government. We coded all Queen's speeches between 1945 and 2007 with a topic code book, based on similar code books used in other countries. In this way, we can examine Dutch agendasetting patterns and assess the effects of coalition composition and coalition life cycle (from the first year a newly formed government is installed to the last year it is still in office) on agenda-setting.

Acta Politica (2009) 44, 1-27. doi:10.1057/ap.2008.16

Keywords: agenda-setting; coalition government; Queen's speeches (Troonrede); issue-attention

\section{Introduction}

Executives and the political parties that control them are, according to democratic theory, central to the demand and supply of public policies. ${ }^{1}$ Governments and parties process all kinds of problems pushed to the political agenda by partisan and departmental actors, interest organizations, media, and 
public opinion. But executive policy agendas are not an open market. In theory, opportunities for bringing issues to the government's attention are infinite. In practice, the flow of attention for problems and solutions is limited by cognitive and institutional bottlenecks. Particularly in systems where governments consist of coalitions of different political parties, the distribution of policy attention may show features of a cartel. After all, coalitions entail political commitments and compromises constraining government's action and attention.

Not all executives, however, are equal. Even within the governments of European parliamentary democracies, there is considerable variation in how they are constructed. The membership of Dutch coalition governments is especially interesting as there never was - given a robust form of proportional representation and many political parties - a complete turnover of the coalition in the post-World War II (WWII) period; at least one party of the new coalition was a member of the preceding coalition. If parties and changes in party control of government are the primary means through which the content of policy agendas is influenced in representative democracies, how does continuity in coalition membership affect agenda-setting? We may expect that incomplete coalition turnover will be accompanied by modest shifts in political attention for policy problems. Such a finding would involve an interesting confrontation with the theory of punctuated equilibrium, which posits that changes in attention occur as episodic shocks (Baumgartner and Jones, 1993; Jones and Baumgartner, 2005).

In this contribution, we provide a first systematic examination of the expectation that coalition continuity results in relative agenda stability by analysing agenda-setting patterns in the Netherlands over the post-WWII period as represented in the annual Queen's speeches to the Parliament. We first examine the nature of Queen's speeches and the Dutch agenda process. We then discuss the coding procedures used to dissect the speeches in terms of policy content. The main part of the paper discusses the macro-structure of the policy agenda reflected in the speeches over the post-WWII period with emphasis on the changes in the patterns of attention associated with changes in governments. To what extent do coalition changes make a difference to the attention that governments pay to policy problems? Such a party effect would support mandate theory, which posits that parties may be expected to be responsive to their voters and fulfil electoral promises when in office (Hofferbert and Budge, 1992); or as a more recent version of this theory predicts, policy emphasizes may reflect the median mandate: a central party has disproportionate influence on the agenda (McDonald and Budge, 2005). If marked shifts in attention occur, are they episodic, as predicted by the theory of punctuated equilibrium (Jones and Baumgartner, 2005), or are developments in political agenda-setting by Dutch governments always 
incremental - reducing payoffs for parties that try to alter the agenda when taking office (Laver and Budge, 1992)? Finally, we conclude the analysis by discussing future work on the nature of Dutch agenda-setting processes in international comparative perspective.

\section{Executive Agenda-Setting and Queen's Speeches in The Netherlands}

Beyond ministerial memoires providing some couleur locale about countries and cabinets, there is an extensive scholarly literature on political executives, particularly on governments in western Europe. This literature deals with the formation and termination of governments (Riker, 1962; Dodd, 1976; Laver and Schofield, 1990; Warwick, 1994; Müller and Strøm, 2000), the mechanisms for enhancing their stability (Strøm and Müller, forthcoming), collective cabinet decision-making, ministerial role performance (Blondel and MüllerRommel, 1993; Laver and Shepsle, 1996), and policy: matrices of party distance are used to map policy profiles and assessments are made of party and government policy positions and policy outputs (Budge and Keman, 1990; Klingemann et al., 1994; Laver et al., 2003).

Yet this extensive scholarly literature on executives fails to explain how political attention is distributed and policy priorities are set as it lacks a longterm perspective on the agenda-setting process, and ignores the fact that governments not only manage large bureaucratic agencies but are also managed by the political parties from which members of government have been selected. This dual nature of governments as departmental and partisan organizations leads to various inputs to which governments have to respond. Yet not every issue presented to them by either departmental or partisan organizations reaches the top of the political agenda. As Blondel and Thiebault (1988) argue, governments are not devices absorbing all matters for collective decisionmaking. Some issues are absorbed and enter the political agenda whereas other issues do not. So how can we explain executive agenda-setting over time?

This question is particularly interesting in the coalition governments of European parliamentary democracies where the agenda-setting responsibility of the executive is often shared by coalition partners. In such coalition situations, government attention for issues may involve even a less linear process than in systems where a single party winning the elections may begin to fulfil its electoral promises as the new government. An especially interesting case is the Netherlands with its long-standing institutional features of large and sometimes 'oversized' coalitions and consociational politics. ${ }^{2}$ Although this peculiar poldermodel was under both public and political pressure in recent years, it still forces the members of the executive - as well as other political actors such as interest groups - to engage in a comparatively extreme form of consensual decision-making. This typical practice of Dutch political life 
extends to the institutional features of the executive. With many political parties, there has never been a complete turnover of political parties in government since 1945. Rather, at least one and sometimes two parties of the old coalition became a new government member. To what extent, then, is the executive able to shift between issues and reset the agenda in such a consensusoriented political system? If such shifts occur particularly in the first year of new governments, this might support mandate theory, which posits that parties taking office begin to deliver electoral promises (Hofferbert and Budge, 1992). But if attention changes are small, this may indicate friction and, perhaps, dominance of a central party (McDonald and Budge, 2005).

To better understand how various institutional features affect executive agenda-setting, a long-term perspective is required. Studying how executive attention changes over time enables us to assess the effects of changes in government composition and 'life cycle phase' of the government on agendasetting. Considering that patterns of priority-setting and decision-making differ between single-party governments and multi-party governments (Weaver and Rockman, 1993; Blondel and Cotta, 2000), how does coalition composition affect agenda-setting? And does a newly formed government reset the agenda more extensively than an incumbent government or than one that is outgoing?

One way to enhance our understanding of the influence of government changes and coalitions on executive agenda-setting is to study the venues that are available to them to present their policy agendas. Within the agenda-setting literature, venues are considered to be vital elements as they are 'institutional locations where authoritative decisions are made concerning a given issue' (Baumgartner and Jones, 1993, 32). One venue to study executive agendasetting in the Netherlands is the annual presentation of government plans on Prinsjesdag, known as the Troonrede (Queen's speech). At the beginning of the new parliamentary year, the Queen addresses both Chambers of Parliament. This speech, written by the coalition government, contains statements about the government's achievements and major events of the previous year and the goals and policy decisions for the year to come. These annual speeches involve symbolic language as they address hopes and concerns about the well-being of the country. But the speeches are not merely ceremonial and symbolic; they tell a story of policy as they contain announcements of new legislative projects and present the government's budget. Even if this is done in a pacifying language, the speeches direct attention to particular problems. Thus, real politics and real public policy are addressed in the speeches.

\section{Coding Queen's Speeches: Approach and Method}

Our coding of the Dutch Queen's speeches follows agenda-setting research conducted in Northern America and more recently in Europe (Baumgartner 
and Jones, 1993, 2002; John and Margetts, 2003; Jones and Baumgartner, 2005; Baumgartner et al., 2006). This research includes different types of policy agendas. In Europe, Queen's speeches and prime minister's addresses are among the first to be systematically analysed (John and Liu (2006) on the UK; Green-Pedersen on Denmark; Chaques et al. (2007) on Spain). A key feature of this emerging work is the use of a similar codebook containing 19 main topic categories and over 200 sub-topics to code agendas in various countries. The Dutch version of the codebook was created in close collaboration with the policy agendas research teams in the US and Denmark. If necessary, sub-codes were adjusted to account for idiosyncrasies related to the Dutch political system. The only major topic category we adjusted was code 21 , which in our scheme includes the typical Dutch policy topic called spatial planning and water management. The list of main topics is given in the Appendix. In addition to the US and Danish codebooks, we introduced two other variables: policy content and Europe. For each sentence or quasi-sentence in the speech, we determined whether the sentence contained a real policy intention mentioning some kind of action in the coming year, a more general argument about a policy problem, or just a ceremonial statement. We also determined for each sentence whether it contained any reference to Europe in general or to specific European Union (EU) institutions. This will enable us to assess the extent to which the domestic agenda is directed by the process of European integration. Our assumption is that the expansion of European policy-making powers becomes visible through references to this level of governance in the Queen's speeches.

We coded all Queen's speeches between 1945 and 2007 at the level of the individual sentence and quasi-sentence. If sentences made reference to more than one policy topic - enumerative statements, for example, occurred in all Queen's speeches - then we coded at the quasi-sentence level. Purely ceremonial statements spoken at the beginning and end of a Queen's speech were not coded by content. We counted these sentences as part of our calculation of the total length of the Queen's speeches.

The data set consists of 8,772 coded sentences and quasi-sentences allocated to one of the 19 main topic categories and into a more specific sub-topic category when applicable. Intercoder reliability checks were made at different stages in the coding process and instances of deviance were discussed and recoded. Coding proved to be highly reliable, with intercoder reliability scores above 0.90 in all cases and well above 0.90 in most cases. In this article, we use the data set to determine which issues were addressed by governments in the annual presentation of their plans, how executive attention has evolved over time, and whether changes in attention followed coalition life cycles. 


\section{Patterns of Executive Agenda-Setting, 1945-2007}

Dutch Queen's speeches always reflect the intentions of coalitions because the Dutch system of extreme proportional representation has constantly produced multi-party governments. Except for a few interim governments, such as the year-long government following liberation in 1945, all of these two-party, three-party, or even five-party coalitions controlled a parliamentary majority. While the institutional rhythm of annual Queen's speeches exists independently of coalitions, party composition may matter to the content of the speech. Below, we analyse whether and how the Dutch politics of accommodation in coalition government becomes visible in the Queen's speeches. We begin with analysing the macro-structure of these speeches and then continue to consider the effects of coalition composition change and coalition life cycles (i.e., first year (new), second or third year, or fourth year (outgoing)) on issue-attention.

\section{General features of Queen's speeches}

Looking at the macro-structure of the 1945-2007 Queen's speeches, we examine the policy content of these speeches through the number of statements they contain and their distribution across policy domains as indicators of government attention. We also examine how attention to different issues has changed over time. The first step is simply determining how many statements the Queen's speeches contained over the period investigated and how many of these were policy intentions for the new parliamentary year. The proportion of policy intentions is a subset of all codable statements in terms of the topics scheme used. As said, Queen's speeches have substantive functions (outlining future policy commitments), symbolic functions (addressing the public's hopes and concerns), and ceremonial functions. The latter were counted but not coded as they lacked substantive content. On average, the proportion of purely ceremonial statements was $9.24 \%$ of all sentences. Some years show more ceremony; in 2005, for example, the 25-year anniversary in the office of Queen Beatrix was mentioned. The degree of ceremonial attention to the Dutch monarchy seems to depend on circumstances and also on individual prime ministers; not all attach equal value to it.

The results reported in Figure 1 bear on these issues. As can be seen in the dark upper line reported in the figure, the number of statements in the Queen's speeches increased markedly from approximately 100 through the 1960s to around 200 in the mid-1980s and 1990s. There was no steady increase, however. Indeed, the earlier part of the time series and the later part are rather different with a discontinuous period of rapid growth during the 1970s and the early 1980s. This period of growth is well reflected in the third-order polynomial regression of the number of statements on year reported in the 


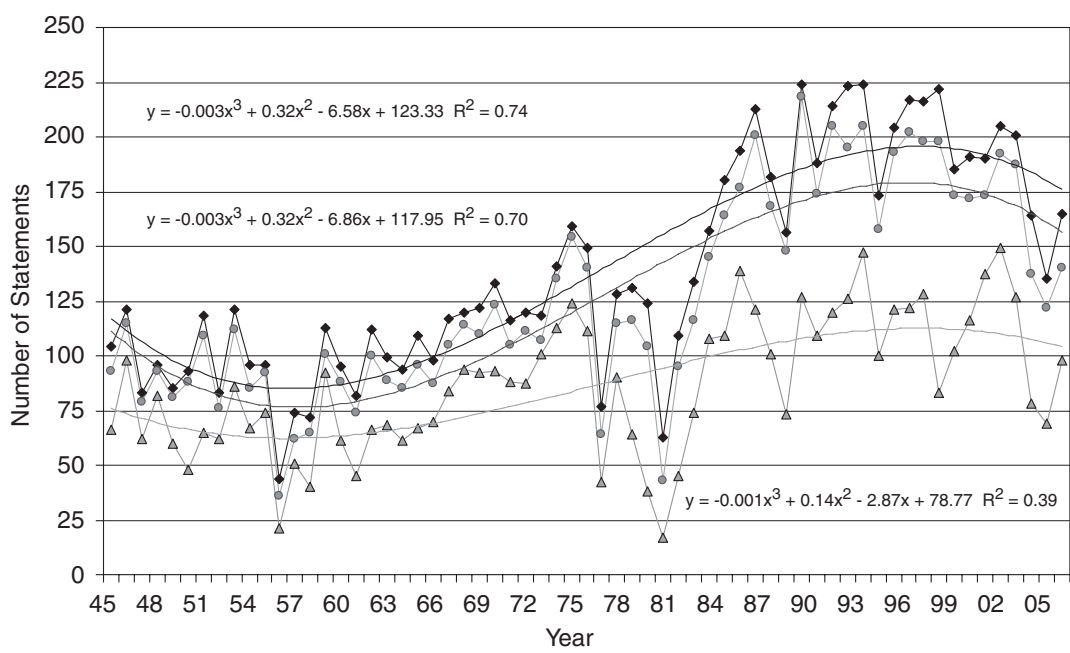

Figure 1 Number of statements (top) and number with policy content (middle) and policy proposals (lower): 1945-2007.

upper-left of the figure, which is represented by the smooth dark line in the figure. ${ }^{3}$ The length of the speeches was stable, grew sharply, and then stabilized over the last 20 years. But that growth is discontinuous in that Queen's speeches were much shorter between 1977 and 1982. Governments did not say much during these years in comparison to the immediate past. One important political reason for this is the occurrence of long interregnums of government formation $(1977,1981)$ during which outgoing governments are expected to just present low key plans. The pattern of growth, however, recommenced in the following years.

More important when analysing Queen's speeches as indicators of executive issue-attention and agenda-setting is our finding that substantial proportions of the statements were actually about more or less doable policy intentions (cf. Van Schendelen, 1976). The numbers of statements with policy content are represented by the pattern in the middle line. It can be seen that not all statements were policy statements; the difference is the ceremonial parts of Queen's speeches. But the figure also shows, in the lighter lower line in Figure 1, that the number of statements we were able to identify as real policy intentions for the coming year follows at some distance. Of the many things that governments had to say about policy problems, only a portion was really policy specific in terms of forward looking and concrete proposals. Over time, this pattern shows the different substantive and symbolic functions of the Queen's speeches. Still, it tracks the total number of statements quite well. 
The temporal evolution of substantive policy intentions for the next parliamentary year is the same as that observed for all statements in postWWII Queen's speeches. Again, the same discontinuous period in the late 1970 s and the early 1980s is observed for policy intentions, when prolonged and difficult government formations took place. These were the years of the two oil crises and an economic recession, which hit the open Dutch economy hard, as well as years of ideological polarization on social issues. For example, the 1981 Queen's speech associated with the Van Agt II government composed of CDA, PvdA, and D66 was rather brief - containing just 63 sentences, of which only 17 were really policy intentions. The almost speechless second Van Agt government was among the most loquaciously challenged coalitions of the last 60 years. But as seen in Figure 1, the preceding Van Agt I coalition prepared the ground with steadily thinner content. Cases of self-restraint also occurred in later years when outgoing governments were presenting their Queen's speech $(1989,1997,2006)$. To some extent, our findings empirically underpin the institutional norm that outgoing governments should not develop major new policy initiatives. A general pattern we observe is that while Queen's speeches became longer over the last 20 years, the proportion of more or less doable policy intentions declined to less than $60 \%$. Individual governments and years show some ups and downs, but the overall trend suggests there are structural causes for this, which will be explained in the next section.

\section{Variation in issue-attention over time}

In more general terms, attention to different kinds of policy varied markedly over the post-WWII period. As can be seen in Figure 2, the total absolute number of statements coded over the whole period using the 19 major topic codes varied from a high of 1,353 for foreign policy issues and 1,124 for macroeconomic issues to a low of 159 for two topics - science and technology and planning - and only 98 for energy issues. These numbers include policy intentions and more general statements about the policy topic. There is, however, considerable variation over time in attention to these issues. This is reflected in Figure 3, which reports the relative proportions of attention to topics over the entire 60 -year period.

The most notable element of Figure 3 is the relative decline in attention to the domains of foreign policy and macro-economic policy, which represent the two largest policy themes in terms of number of statements. This mostly was early attention; until the late 1960s, these fields together obtained almost half of all attention in Queen's speeches. The relative decline in attention for these two fields involved different patterns. For macro-economic policy, the decline is not just relative as other issues have crowded the political agenda; the absolute number of statements dropped as well. In contrast, attention to 


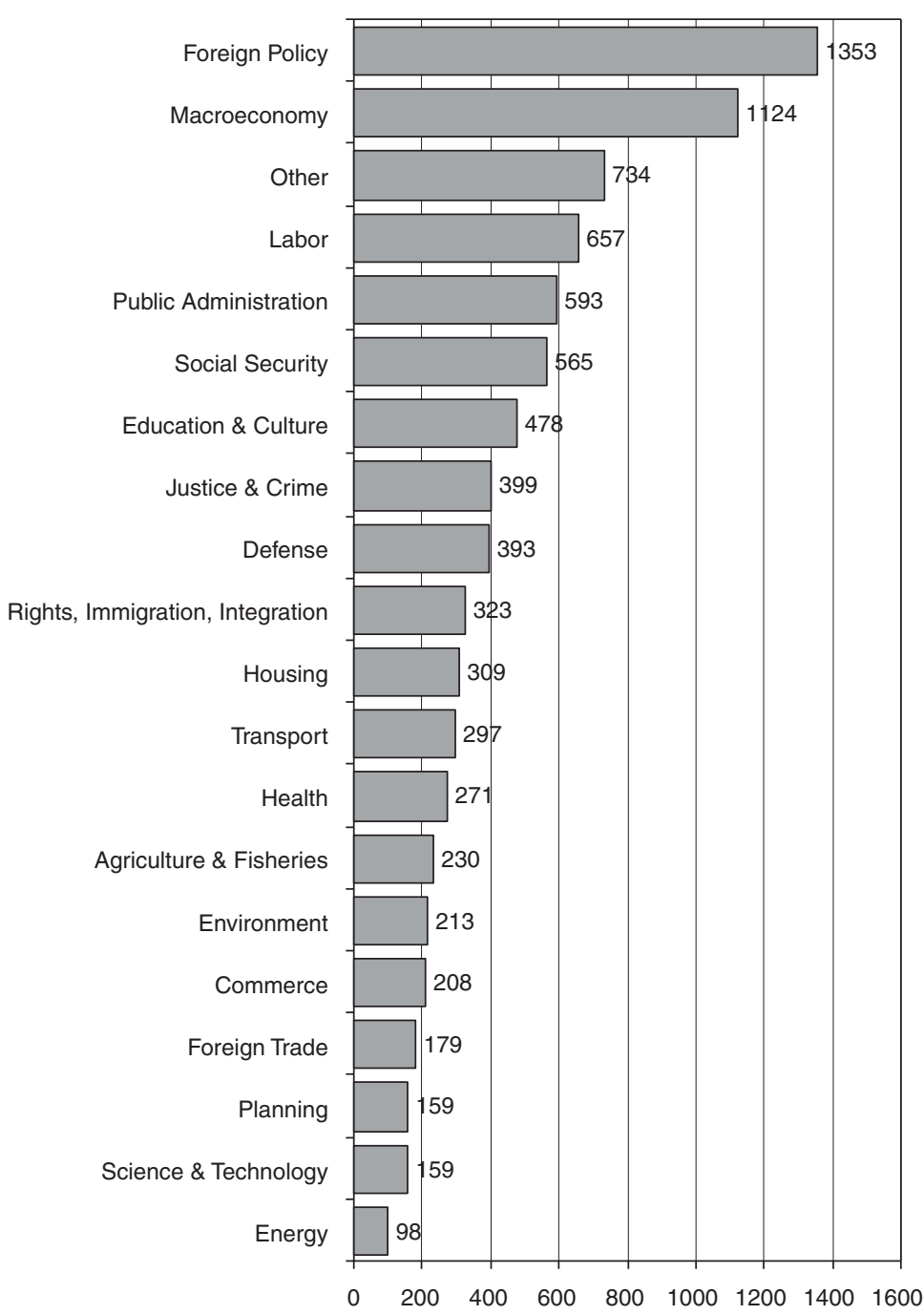

Figure 2 Number of statements by policy area, 1945-2007.

foreign affairs in terms of number of statements in annual Queen's speeches actually trended upward, with the 1990s even representing a high point in absolute attention. But the expansion of the scope of governmental attention has led to a relative decrease in attention for foreign policy.

The trend towards more crowding on the Dutch policy agenda is visible in Figure 4, which reports annual values of a Herfindahl index of policy attention. 


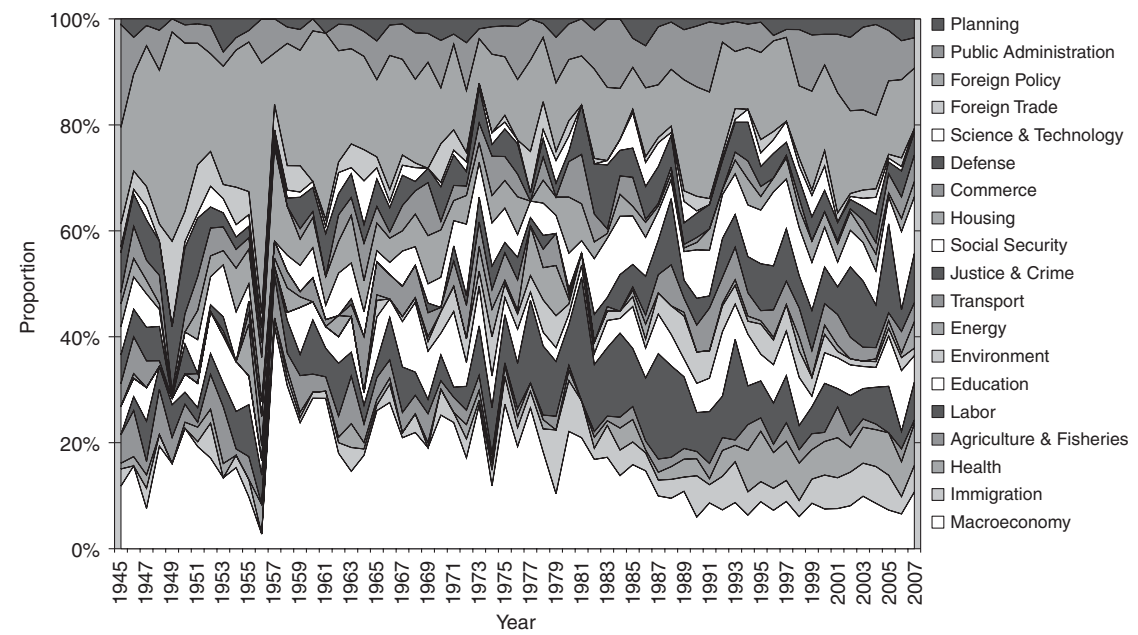

Figure 3 Relative distribution of coded policy topics by major code, 1945-2007.

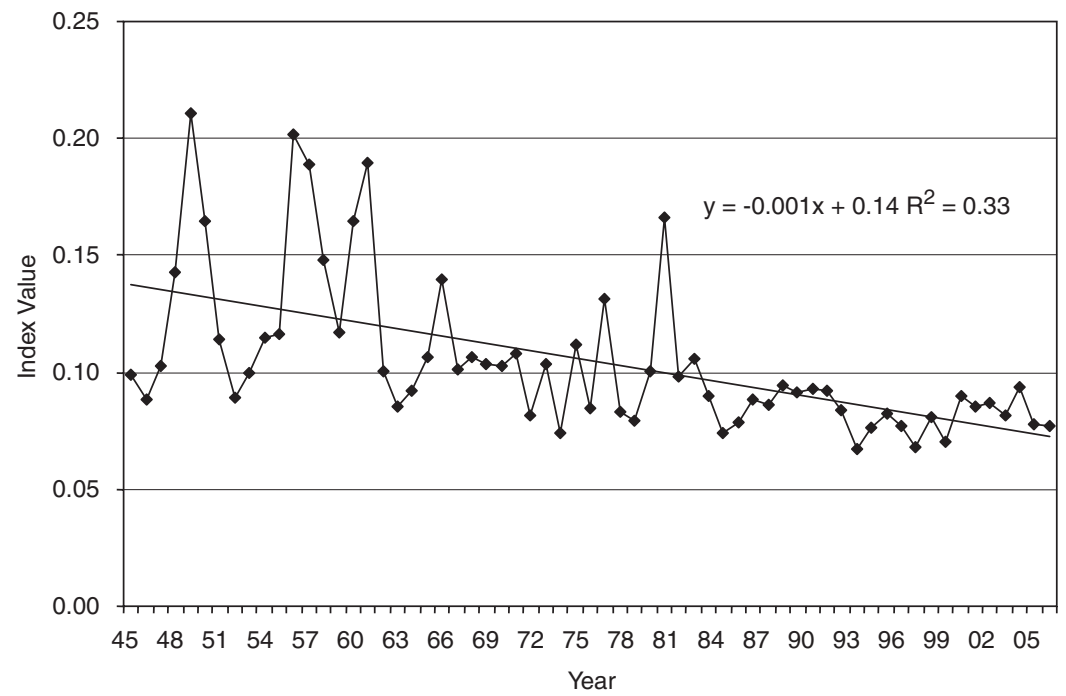

Figure 4 Herfindahl index of policy topic concentration, 1945-2007.

Herfindahl indices are calculated by summing the squared proportions of an item, in this case the proportions of statements in each speech addressing one of 19 major policy topics. Thus, a value of 1.0 would indicate that attention was given to only one of the 19 policy topics and a value near zero would 
indicate that attention was spread evenly across the issues. Although the pattern is somewhat heteroskedastistic through the early 1960s, there is a rather marked linear decline in the annual Herfindahl values reported in the figure. Recent governments gave more even-handed attention to a wider array of issues. This suggests that the Dutch policy agenda became much more crowded in recent decades if number of statements in the Queen's speeches devoted to different topics is a valid measure of policy attention.

Turning to another often observed feature of temporal analyses of policy agendas, we tested whether changes in attention to specific policy topics had a leptokurtic distribution, which is a characteristic of punctuated equilibrium processes. Unlike normal distributions, processes governed by punctuated equilibrium show leptokurtic frequency distributions, that is, limited change most of the time but episodic large change. Such frequency distributions tend to have high central peaks, reflecting small change and fat tails of major change (Jones and Baumgartner, 2005). We examined changes in attention to issues in several ways, including simple first differences in the proportions to our 19 major topics and such differences as a proportion of all of the statements in the speeches. Both produced strong evidence of leptokurtosis. But we report a third test in Figure 5 because it, more than the other tests, illuminates how some issues simply drop off the agenda. We calculated the change in proportional attention to a given topic among the 19 major topics from one year to the next as a proportion of the prior year's proportion. ${ }^{4}$ As seen in the strongly left-censured figure, there is a large central peak representing limited

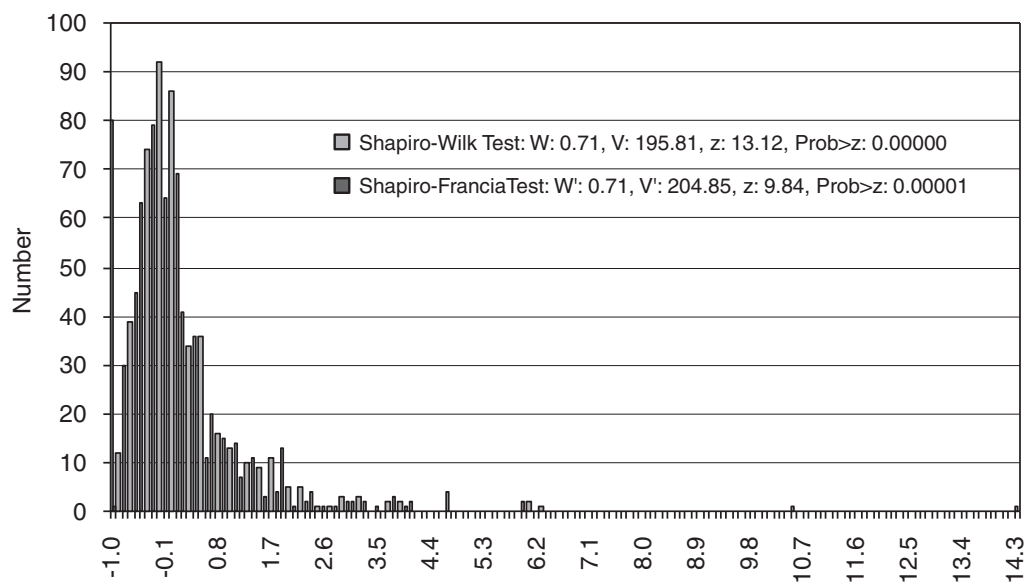

Pct. Change in Number of Statements

Figure 5 Frequency distribution of percent change in annual number of statements with topics, $1945-46$ to $2006-7(n=1,092)$. 
change in attention. Moreover, there are fatter than expected tails for a normal distribution. On the positive side of the distribution, attention to some issues has increased markedly. More interestingly, the extreme peak on the left side of the distribution suggests that a large number of issues drop off the agenda as they show a $100 \%(-1.0)$ reduction in number of statements as a proportion of the prior year's number. As seen in the strong kurtosis test results reported at the bottom of the figure, these findings suggest that executive attention for policy problems can be characterized as a punctuated equilibrium process. This is interesting, as it raises the question about the time intervals: do such attention shifts follow coalition cycles or is there a different logic in this episodic pattern? We will deal with this question further below when assessing possible effects of coalition composition.

While our analysis of the Herfindahl scores of entropy in the policy agenda process and the leptokurtic pattern underlying changes in attention tell us much about the big picture of the politics of attention in the Netherlands, it also masks real differences in patterns of attention to specific issues. When we examine the temporal paths of statements about each of the 19 policy domains separately, it seems clear that changes in the level of attention accorded to specific issues in Queen's speeches do in fact reflect several quite different processes. The evolving patterns of issue-attention we find seem plausibly connected to changes in the policy environment over the past half century. Some evidence of this is presented in Figures 6a to 6f, which for several policy themes report the numbers of statements per year as a proportion of the total number of statements. The trendlines in Figures $6 \mathrm{a}$ to $6 \mathrm{f}$ are the lines of best fit generated by regression of number of statements on year with the statistical results reported in the figures. With the exception of the last simple linear relationship, second-order polynomial regressions generated the best fit. We selected the policy themes to show exemplars of several distinct typical patterns of change in levels of policy attention. ${ }^{5}$

Several traditional policy areas, such as defence and labour, show a similar pattern to that reported for macro-economic policy in Figure 6a. They rise and then decline over time. As is evident for macro-economic policy, the peak of attention occurred in the mid-1970s. This decline is more than relative as a result of discussing newer issues; there are simply fewer statements about these issues in more recent Queen's speeches. But as Figure 6b shows, decline in attention is not an exclusive property of more traditional policy concerns. Attention to environmental issues, which grew rapidly from the mid-1960s to the mid-1990s, declined sharply at the turn of the century. ${ }^{6}$ Indeed, the first three Balkenende governments devoted just one or two sentences to environmental issues each year. In its first speech in September 2007, the Balkenende IV government included two statements on the environment, but also eight on energy policy, which may reflect an 'Al Gore-effect'. This 

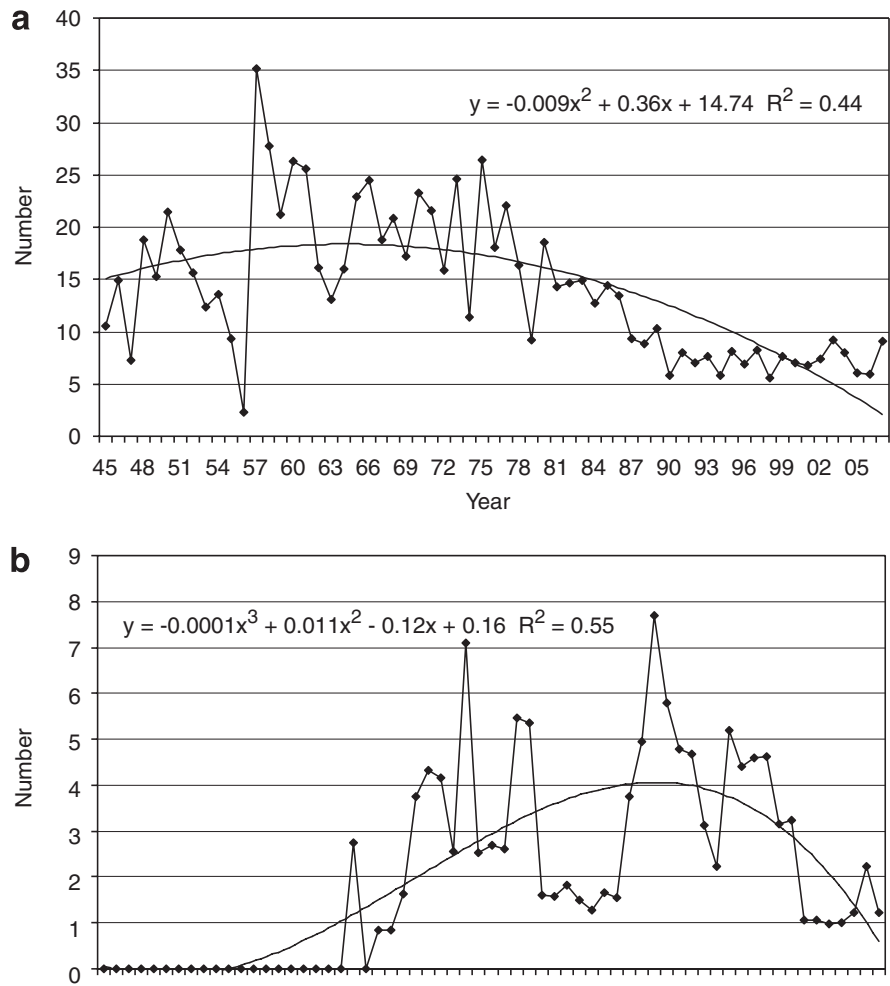

$\begin{array}{lllllllllllllllllllll}45 & 48 & 51 & 54 & 57 & 60 & 63 & 66 & 69 & 72 & 75 & 78 & 81 & 84 & 87 & 90 & 93 & 96 & 99 & 02 & 05\end{array}$ Year

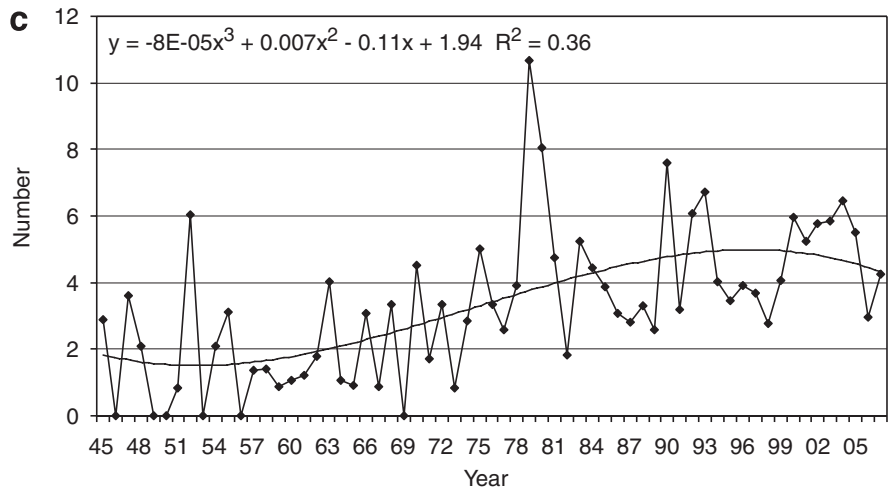

Figure 6 (a) Rise and decline: Pct. of macroeconomic statements: 1945-2007. (b) Rise and decline: Pct. of environmental statements: 1945-2007. (c) Rise and decline: Pct. of rights, immigration, and integration statements: $1945-2007$. 

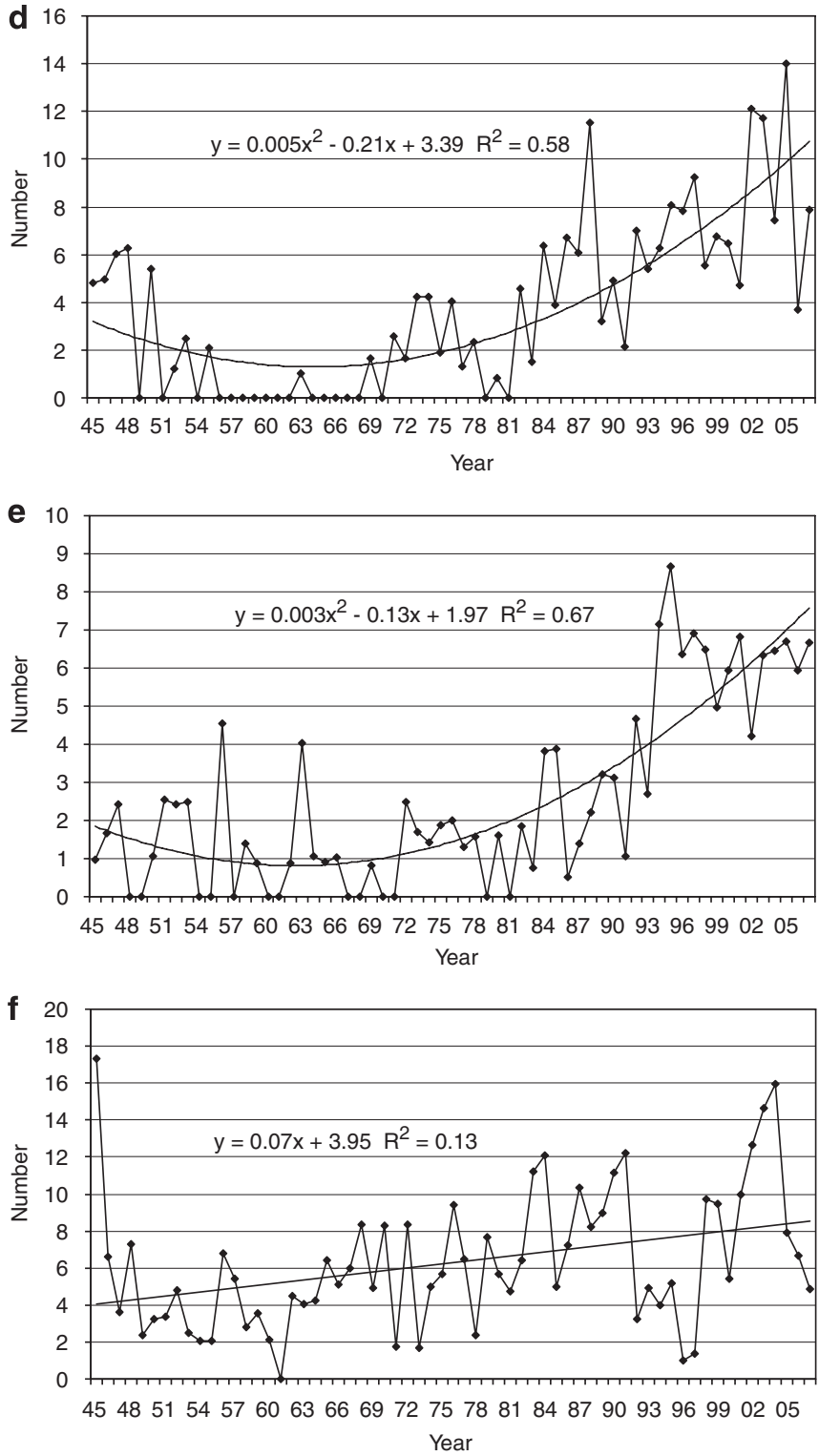

Figure 6 (d) Rise and decline: Pct. of justice and crime statements: 1945-2007. (e) Rise and decline: Pct. of health statements: 1945-2007. (f) Rise and decline: Pct. of public administration statements: 1945-2007. 
attention pattern in the Dutch executive agenda supports Down's issueattention cycle (1972) in which environmental concerns are low when the economy is in trouble, and 'green' issues receive more attention in periods of economic growth.

Another set of issues reflects growing patterns of attention. In some cases, as for the environment and to a lesser extent also for rights, immigration, and integration as seen in Figure 6c, increased attention in the form of more statements in Queen's speeches has grown slowly since 1970 and levelled off recently. Attention to social security issues developed in the same manner. In other cases, although a clear interpretation of more recent years is difficult, attention seems still to be rising. These cases are well represented by justice and crime policy in Figure $6 \mathrm{~d}$ and health policy in Figure $6 \mathrm{e} .{ }^{7}$ But it seems that both have their own unique trajectories, with attention to crime and justice issues taking off several years before the recent upswing in attention to health (which began in the late 1980s). And in still another pattern, Figure 6f indicates that the nominally staid theme of public administration produces a simple linear pattern of increase as governments have used more time in the Queen's speeches to discuss their own structures for providing goods and services. This topic includes issues associated with reform of democratic institutions election of prime minister and mayors, introduction of referenda - for which some parties pressed continuously as their signature issue since the late 1960s. But these often are a case of what Edelman (1977) called 'Words that succeed, but policies that fail' (p. 1).

Other policy areas - agriculture and fisheries, education, energy, commerce, science and technology, transportation, and spatial planning - appear to be more erratic in terms of the temporal paths of attention accorded to them. They appear to have discontinuous attention patterns with greater attention accorded when quite specific issues arise, and then disappear from the agenda. Government frequently ignored these policy areas; energy, for instance, was only mentioned in half of the Queen's speeches. Some of these fields not only seem sensitive to external shocks and events, but also to the existence of a senior or junior cabinet portfolio. Such portfolios are not fixed in the Netherlands and this is a mechanism through which executive attention can be directed and sustained. If a topic has no ministerial representation, it is easily overshadowed by other matters that are more prominently addressed through the portfolios represented by government ministries.

Finally, for mapping the overall patterns of attention over time, we included a code mentioning whether Europe (either generally or EU institutions specifically) was mentioned in a sentence. These results are reported in Figure 7. This variable was coded for all statements, not just for statements about Europe as a topic in the foreign policy category (category 19). We did this to examine the extent to which governmental statements, even on domestic 


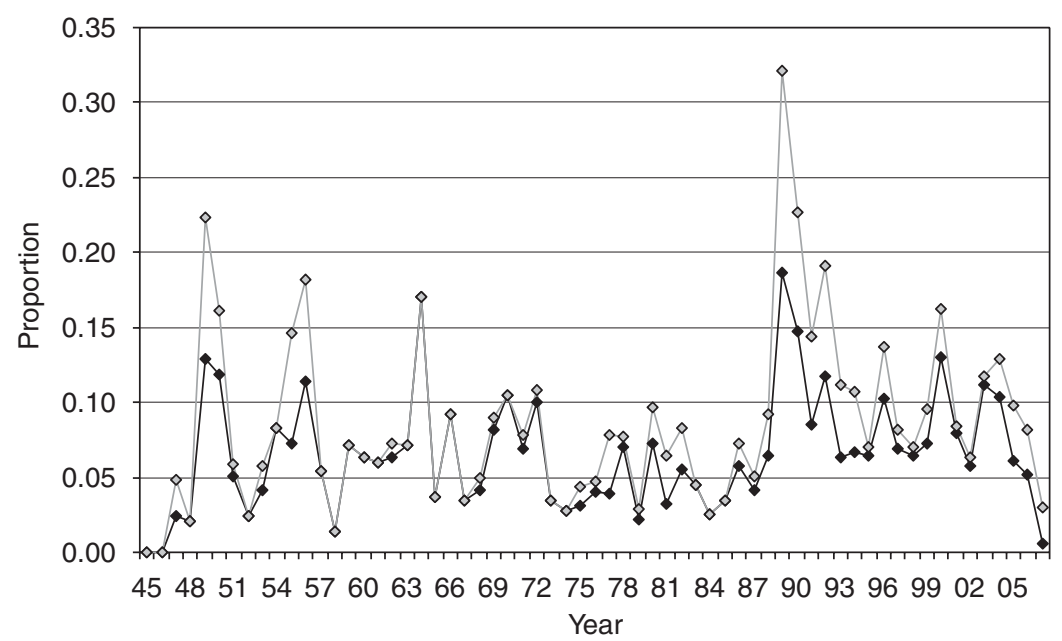

Figure 7 Proportion of statements with general European (light) and European union institutions (dark) content, 1945-2007.

issues, reflect the ongoing processes of EU integration. The lighter line represents the proportion of the more inclusive statements mentioning Europe in any manner in annual Queen's speeches; the dark line includes the more strictly defined cases of reference to EU institutions. The two trends track each other quite well. The key point to note about the figure is that the trend is generally quite flat with several well-defined spikes associated with the BENELUX agreement, the establishment of the European Coal and Steel Community, and the efforts to establish a single European market. In this case, it seems that the government mentioned Europe or EU institutions in any of the policy statements only in years of important steps towards EU integration. In other years, policy statements simply were framed with much less reference to the EU level of governance. ${ }^{8}$

\section{Attention and multi-party government}

Governments drafting the Queen's speech may have different incentives to set topic and tone. From the perspective of democratic theory, an important source of such variation concerns the composition of governments. It is often said that political parties emphasize different policy themes, speaking to different constituencies containing voters with different economic, social, and religious backgrounds. ${ }^{9}$ Mandate theory similarly predicts that parties in government converse election pledges into policy choices (Hofferbert and Budge, 1992; McDonald and Budge, 2005). In this part of the analysis, we 
examine the possible effects of coalition composition of new governments and of government status on issue-attention. If non-incremental or punctuated changes occur (as indicated in Figure 5), are they congruent to coalition life cycles as might be expected by democratic theory and mandate theory, or are they unrelated to them? If they are unrelated, what then causes such punctuations and why do they not occur when governments change? Could this be an effect of the incomplete turnover of coalitions, in which one or two parties stay in office and limit the possibility to provoke an attention shift by a new partner? Or are such change constraints even imposed by a single central party, as median mandate theory suggests?

To assess how Queen's speeches have changed in terms of policy content from year to year, we generated correlation coefficients for the number of statements coded under each of the succeeding pairs of years. This is a more exact measure of the change patterns visible in Figure 3, showing the overall ups and downs in policy attention graphically. Thus, for example, a correlation of 0.929 for 1978 means that the relative distribution of statements by topic in the 1978 speech hardly differed from that in 1977. In contrast, the low correlation of 0.160 in 1957 indicates a major shift in attention compared to what was being paid attention to in 1956. The full distribution of correlations is presented in Figure 8 showing a high degree of stability in attention to policy topics from year to year.

Real topic attention jostling was rare. In less than a third of the paired years did the correlation drop below 0.750 , and only three times did a government

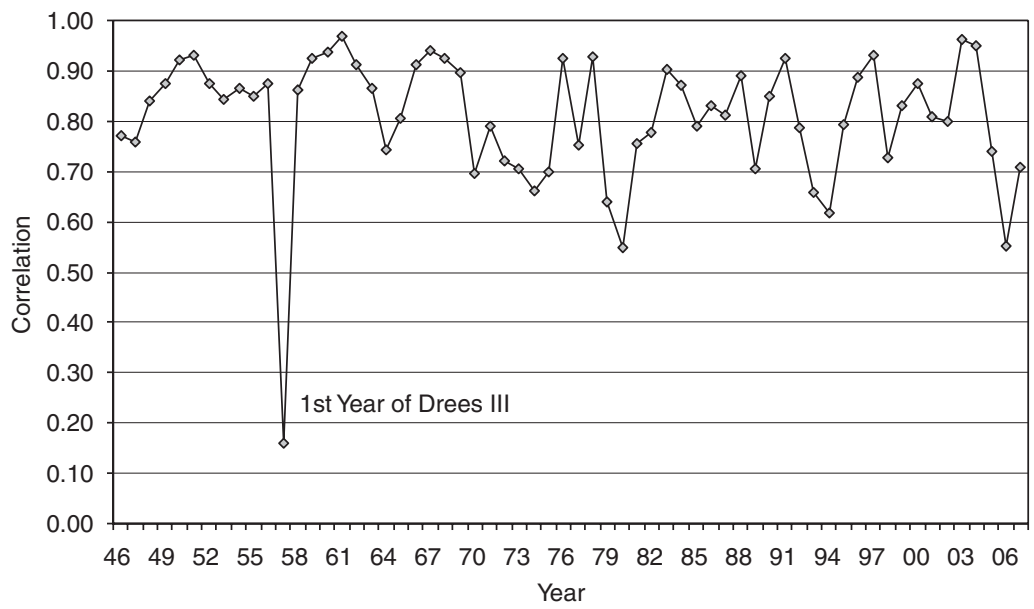

Figure 8 Correlation coefficient of number of statements by topic areas from one year to next, 1945-46 to 2006-07. 
shift attention to policies in the Queen's speech to such an extent that the correlation with the previous year was under 0.600 (1957, 1980, and 2006). The case that stands out is 1957, when the new Drees III government devoted much more attention to macro-economics and housing compared to the preceding Queen's speech of 1956. The 1956 speech was devoted to international tensions, that is, problems with Indonesia and New Guinea; the latter still being a Dutch colony striving for independence. Indonesia was already independent, but wanted to annex New Guinea. Interestingly, only one sentence in the 1957 Queen's speech addressed the issue, even though the government knew that the UN planned to vote on whether or not New Guinea should remain under Dutch government in November 1957. It seems as if the government deliberately avoided the politically sensitive topic by emphasizing the declining national economic situation - low income and increasing budgets - and housing shortages. Foreign affairs returned to the agenda in 1958, although it took another year before the issue received the same level of attention as in the period prior to the New Guinea crisis. Additionally, macro-economic issues remained higher on the agenda for a couple of years following the New Guinea crisis than it did before 1957.

Low correlations also apply to some years in the 1970s, when political aspirations became more outspoken and polarized than in preceding years. The topics changed from year to year, shifting from unemployment policies to social security issues without a clear pattern. We can, however, explain the low correlation between 1973-1974 and 1974-1975. In these years, the Dutch government considered introducing new tax regulations. This issue received broad attention in 1973 and 1975, but was largely absent in the 1974 speech (correlation between 1973 and 1975 is 0.93). The 1974 speech became even more deviant compared to 1973 and 1975 as a result of a temporarily increase in attention for international developments. In 1974, Greece and Portugal became democracies - events deemed worthy of mentioning in the Queen's speech and were used by the government to proclaim the importance of democratization (esp. the former Portuguese colonies) and announce extra development and relief aid.

External circumstances caused the low correlation between 1979 and 1980. Rising energy prices and its consequences for the transport sector dominated the 1979 speech. This increase in attention for energy(-related) issues was probably the result of the oil-boycott against the Netherlands in response to its support for Israel, although this boycott is not explicitly mentioned in the speech. In 1980, however, the attention shifted completely towards the overall deteriorating economic situation and the problems it caused to industry, housing, and commerce. The energy issue had disappeared from the agenda.

External events partly explain the low correlation between 1992 and 1993. The 1993 Queen's speech hardly paid any attention to foreign affairs whereas 
the Queen's speech of 1992 (as well as 1991 and 1990) was filled with foreign affairs issues such as the armed conflict in former Yugoslavia, famine in Africa, and the signing of the EU treaty (Maastricht) in 1992. New policy plans concerning the labour market offers the other part of the explanation for the low 1992-1993 correlation. The government announced various policy plans for subsidizing labour and linking education and unemployment benefits in its 1993 speech.

Interestingly, the Lubbers III cabinet announced these labour plans in 1993 (left-wing, with a Christian democratic prime minister), but Kok I implemented them the following year ('Purple' cabinet consisting of Liberals and Labour; Kok being a Labour PM). Apparently, Lubbers III's Labour members were able to announce new policies in the 1993 speech, before they took power in 1994. Moreover, following the elections, the newly elected Purple cabinet had no need to pay much attention to the labour plan and shifted its attention to health, education, and agriculture. Especially health reform policy was high on the agenda. This shift in attention mainly explains the low 1993-1994 correlation.

The last low correlation to be explored is the 2005-2006 correlation. Hot issues such as labour market reform and justice were high on the 2005 agenda, remained almost absent in the 2006 speech, and returned back on the agenda of 2007. Interestingly, there is also a low correlation between Balkenende's 2005 and 2006 speeches, indicating that the Balkenende II government was searching for new topics and tone to address the changing public mood.

We also assessed change rates for different coalitions. We compared years in which a new government took office with years when the Queen's speech was produced by an incumbent government in its second or later year in office. Our expectation would be that changes in attention are larger if a new government coalition takes office - making its own fresh emphasis on policy topics (Bunce, 1980) and speaking to its new electoral mandate (Hofferbert and Budge, 1992). We examine this expectation in Figure 9, which presents the average year-to-year correlations, differentiating between governments continuing in office, new governments with similar parties, and new coalitions.

The first bar in Figure 9 represents the average year-to-year correlations of statements by the major topic codes for the total of 38 years in which an incumbent government continued in office (i.e., the second, third, or fourth year in office). As we expected, the value of 0.824 is the highest of the several values in the figure. The second bar represents years in which a new government made its maiden Queen's speech. This happened 24 times in the period 1945-2007, and the value of 0.781 shows that such fresh governments were somewhat less path-dependent in devoting attention to policy problems. These 24 cases contain all governmental first years, involving both continuity and changes in coalition composition. When differentiating 


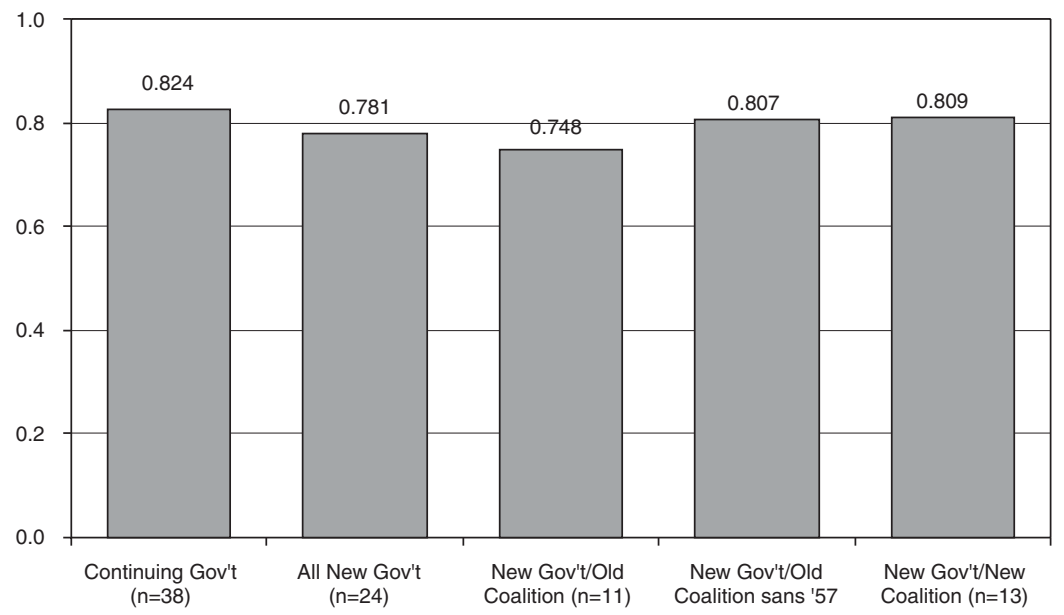

Figure 9 Average correlation coefficient between succeeding years' distributions of statements by topic area by government type.

for this composition aspect, as seen in the third, fourth, and fifth bar in Figure 9, it appears that the 11 new governments presenting a Queen's speech of a - at least partially - different coalition colour than their predecessor were less inclined to demonstrate attention shifts than new governments involving a continuation of the same parties (the values are 0.748 and 0.809 , respectively). This pattern appears also if we exclude the exceptional year of 1957 - when a major attention shift happened in the first year of the Drees III government $(0.807)$. These are counterintuitive and interesting findings. They contradict mandate theory, which posits that new parties in government are held to deliver what they promised in the elections (Keeler, 1993). We discuss these findings in the next section.

\section{Discussion and Conclusion}

Newly appointed governments only modestly change the distribution of attention for major policy topics, and entirely new coalitions, in most cases, even seem relatively averse of redirecting political attention in their first Queen's speech. ${ }^{10}$ While in the Dutch institutional context an 'entirely new coalition' never involves a complete coalition turnover, it is remarkable that a partial turnover seems to produce even less changes in emphasis in Queen's speeches than when an unchanged government prolongs its term in office. Changes in coalition thus do not seem to be special occasions for governments to alter the major topics of policy conversations - at least not as expressed in 
the Queen's annual address. This is interesting, because coalition agreements made during government formation are often used to present new policy initiatives and set a different tone - which one may expect to be reflected in the new coalition's maiden Queen's speech. But such an overt public display of policy ambitions in Queen's speeches does not take place.

There are three possible explanations for this result and the puzzle it raises about executive issue-attention in the Netherlands. The first points to the public relations function of Queen's speeches. Queen's speeches and the surrounding events in which the Queen takes a tour in a golden carriage pulled by eight horses have an important symbolic function. The Queen's speeches may be used to shape the overall image of policy problems and less for highlighting the fine print of policy proposals. We think that this first explanation is unlikely, however, given our finding that, on average, more than $90 \%$ of the content of Queen's speeches is substantive policy talk. If the goal was just public relations, there would be no need to address policy so thoroughly.

Second, the rather low degree of changes in policy attention accompanying government change may reflect the nature of Dutch coalition governments. The politics of consensus and compromise may be institutionalized to such an extent that changes in coalition composition - incomplete as they are - are not used to shift issue-attention. Even during the biggest political change in 1994, when the Christian Democrats were out of office for the first time since 1945, Labour had already instigated policy plans during the preceding Lubbers government led by a Christian Democratic prime minister. The secular coalition made relatively large attention changes in its first year in office, and our findings contain some evidence for the expectation from mandate theory that these attention changes follow from electoral promises made by the new coalition partners. But overall, our findings seem to testify more to median mandate theory (McDonald and Budge, 2005): the Christian Democrats seem to have used their long-standing central position for hampering attempts by new coalition partners on their right or left to shift attention.

However, given our general finding that the overall long-term pattern of changes in issue-attention displayed in Queen's speeches is leptokurtic (i.e., shows small changes most of the time but also larger episodic shifts), we may be facing something called the incubation time of change (Polsby, 1984). Our finding that governments prolonging their stay in office seem more inclined to shift issue-attention than new governments suggests that the change process takes longer than a single governmental term. This may well be consistent with the idea in punctuated equilibrium theory that major changes result from processes of feedback. These feedback processes build up and can take a decade or more before the problem is considered urgent enough to pay attention to it (Baumgartner and Jones, 1993). 
This explanation of incubated attention change may be examined further in two ways. First, policy agendas projects currently coding agendas in countries characterized by different patterns of government composition (e.g. UK, Denmark, and Spain) will generate data we can use for comparative analysis. Second, attention in the Netherlands may be studied by comparing the Queen's speech data set with data sets on other Dutch executive agendas. These agendas include (a) coalition agreements that are made every time a new government is formed and in which governments may more boldly assert which topics will be addressed in years to come; ${ }^{11}$ (b) political party programmes that show partyspecific intentions; (c) departmental budgets containing chapters in which money talk is justified in policy language; and (d) agendas of cabinet meetings that give insight into the government's priorities on a week to week basis. All these sources constitute elements in the democratic chain of delegation, from voters through parties to executives setting out to take action in the name of the people. ${ }^{12}$ This empirical research may also inform the existing theoretical and spatial models based work on party mandates and median mandates.

The third possible explanation for the pattern of relative continuity in issueattention beyond 4-year governmental life cycles (or shorter if governments collapse prematurely) is the general expectation that governments address a common set of issues. Every government - no matter its composition - needs to address a common set of policy problems; a set that has expanded with the build-up of the welfare state in the 1960s and 1970s. The increased length of speeches probably testifies to this development, as does the Herfindahl index which shows increasing policy topic concentration over time (see Figure 4). If true, then the largest variation will not be found in the pattern of attention to policy problems, but in the kinds of solutions proposed to solve this expanded set of policy problems, as well as in the way problems get defined over time. In future research, we will examine the common set of issues-explanation through a more detailed assessment of the policy topic sub-codes and case analyses of specific policy issues. Indeed, the major topics in the speeches may contain more diversity than our analysis can reveal. In this paper, we focused on the major policy topics to which Dutch governments in office between 1945 and 2007 devoted public attention. Behind these general categories are multiple sub-topics of issues that governments addressed and on which they may vary. For example, two governments devoting the same proportion of statements in their speech to health issues may use different problem definitions and solutions, highlight different subjects of health policy (e.g., medicine regulation or interventionist programs of public health provision), or announce policy adjustments or advocate redesigning entire health provision system. Thus, major topic codes only provide part of the picture. Sub-topic analysis is needed to say more precisely which part of a policy issue a government is addressing and qualitative analysis may help reveal how executives frame policy problems. 
Our general finding that the pattern of ups and downs in attention for major policy themes shows small changes most of the time with episodic larger shifts (a leptokurtic pattern deviating from a normal distribution) may or may not be supported when analysing the pattern of attention at the level of policy subtopics.

Determining which of these three possible answers best explains the modesty of newly appointed governments in introducing new issues requires more research on the politics of executive attention in the Netherlands. The analysis of Queen's speeches in this article really marks the beginning of a line of research on attention to policy problems in the Netherlands using longitudinal data sets and investigating change patterns and their causes. This research is closely linked to similar work in other countries, both existing and still emerging. As such, the empirical data collected for this paper are not just relevant for understanding the Dutch case, but are part of broader crossnational comparative work on issue-attention in democratic systems.

\section{About the authors}

Gerard Breeman is a lecturer at the Department of Public Administration at Wageningen University (the Netherlands). His Ph.D. thesis (2006) focuses on the role of trust in the Dutch agricultural sector. His interests include trust, policy-making, and collective action. His publications include an analysis of EU agricultural reform in Reform in Europe. Breaking the Barriers in Government (Ashgate, 2006).

David Lowery is a professor at the Department of Public Administration at Leiden University. Professor Lowery teaches and conducts research on research methods, the politics of interest representation, urban politics and administration, bureaucratic politics, and tax and spending policy. He has authored a number of papers on these and other topics that have appeared in such professional journals as the American Political Science Review, the American Journal of Political Science, and the Journal of Politics.

Caelesta Poppelaars is a research fellow at the Department of Public Administration at Leiden University (the Netherlands). Her research interests include bureaucratic politics, interest representation, comparative politics, decision-making and policy implementation. She has published several articles on immigrant integration policy and is currently finishing her dissertation on bureaucracy-interest group interactions in comparative perspective.

Sandra L. Resodihardjo is a lecturer at the Department of Public Administration at Leiden University (the Netherlands). Her Ph.D. thesis (2006) focuses on the crisis-conditions leading to reform in Dutch and British Prison Services. In 2007, she worked at Manchester University (England) for 2 months as a Hallsworth Visiting Professor. She teaches and conducts research on reform, 
policy change, crises, prison services, inquiries, and agenda-setting processes. She co-authored and co-edited Reform in Europe. Breaking the Barriers in Government (Ashgate, 2006) and published in journals such as Journal of Contingencies and Crisis Management and Journal for Crime, Conflict, and the Media.

Arco Timmermans is a lecturer at the Department of Public Administration at Leiden University (the Netherlands). He obtained his Ph.D. at the European University Institute in Florence (1996) and has worked as a guest lecturer at several universities across Europe. His research focuses on coalition politics and agenda-setting in the Netherlands and abroad. He published High Politics in the Low Countries (Ashgate, 2003) and authored articles in international journals such as Acta Politica, European Journal of Political Research, Journal of Comparative Policy Analysis and Journal of European Public Policy as well as numerous articles in Dutch journals and newspapers. He is a steering committee member of the new ECPR Standing Group on Comparative Political Institutions.

Jouke de Vries is a professor at the Department of Public Administration at Leiden University (the Netherlands) and the academic director of the Campus The Hague. His main research focus is on the relation between politics and administration. He founded the Grotius Centre for International Legal Studies and the Centre for Government Studies. He (co-)authored numerous books, including Controlling Public Expenditure. The Changing roles of Central Budget Agencies - Better Guardians? (Edward Elgar, 2003), and published many articles in journals such as Public Administration.

\section{References}

Baumgartner, F.C., Green-Pedersen, C. and Jones, B. (2006) 'Comparative studies of policy agendas', Journal of European Public Policy 13(7): 959-1132.

Baumgartner, F. and Jones, B. (1993) Agendas and Instability in American Politics, Chicago: University of Chicago Press.

Baumgartner, F. and Jones, B. (2002) Policy Dynamics, Chicago: University of Chicago Press.

Blondel, J. and Cotta, M. (eds.) (2000) The Nature of Party Government. A Comparative European Perspective, New York: St. Martin's Press.

Blondel, J. and Müller-Rommel, F. (eds.) (1993) Governing Together. The Extent and Limits of Joint Decision-Making in Western European Cabinets, New York: St. Martin's Press.

Blondel, J. and Thiebault, J. (1988) 'The study of Western European cabinets', European Journal of Political Research 16(2): 115-123.

Budge, I. and Farlie, D. (1984) 'Party Competition - Selective Emphasis or Direct Confrontation?', in H. Daalder and P. Mair (eds.) Western European Party Systems, Beverly Hills: Sage, pp. 267-305.

Budge, I. and Keman, H. (1990) Parties and Democracy, Oxford: Oxford University Press.

Bunce, V. (1980) 'Changing leaders and changing policies: the impact of elite succession on budgetary priorities in democratic countries', American Journal of Political Science 24(3): 373-395. 
Chaques, L., Palau, A. and Munoz, L. (2007) 'The prioritization of issues by the Spanish executive: Fragmentation, volatility and issue visibility of prime minister speeches', ECPR General Conference, Pisa.

Dodd, L. (1976) Coalitions in Parliamentary Government, Princeton: Princeton University Press.

Downs, A. (1972) 'Up and down with ecology — the "issue-attention cycle", The Public Interest 28(2): 38-50.

Edelman, M. (1977) Political Language: Words that Succeed and Policies that Fail, New York: Academic Press.

Hofferbert, R.I. and Budge, I. (1992) 'The party mandate and the Westminster model: election programmes and government spending in Britain, 1948-85', British Journal of Political Science 22(2): 151-182.

Jennings, W. and John, P. (2007) 'Punctuations and turning points in British politics? The policy agenda of the queen's speech, 1940-2005', IPEG Working Paper.

John, P. and Liu, H. (2006) 'The policy agenda in the United Kingdom: a longitudinal analysis of queen's speeches, 1990-2006', ECPR Joint Sessions, Nicosia.

John, P. and Margetts, H. (2003) 'Policy punctuations in the UK: fluctuations and Equilibria in central government expenditure since 1951', Public Administration 81(3): 411-432.

Jones, B. and Baumgartner, F. (2005) The Politics of Attention. How Government Prioritizes Problems, Chicago: University of Chicago Press.

Keeler, J.T.S. (1993) 'Opening the window for reform: mandates, crises and extraordinary policymaking', Comparative Political Studies 25(1): 433-486.

Klingemann, H.D., Hofferbert, R. and Budge, I. (1994) Parties, Policy, and Democracy, Boulder: Westview Press.

Laver, M., Benoit, K. and Garry, J. (2003) 'Estimating the policy positions of political actors using words as data', American Political Science Review 97(2): 311-331.

Laver, M. and Budge, I. (eds.) (1992) Party Policy and Government Coalitions, London: Macmillan.

Laver, M. and Schofield, N. (1990) Multiparty Government. The Politics of Coalition in Europe, Oxford: Oxford University Press.

Laver, M. and Shepsle, K.A. (1996) Making and Breaking Governments: Cabinets and Legislatures, Cambridge: Cambridge University Press.

McDonald, M.D. and Budge, I. (2005) Elections, Parties, Democracy: Conferring the Median Mandate, Oxford: Oxford University Press.

Müller, W.C. and Strøm, K. (eds.) (2000) Coalition Governments in Western Europe, Oxford: Oxford University Press.

Polsby, N. (1984) Political Innovation in America. The Politics of Policy Innovation, New Haven: Yale University Press.

Riker, W. (1962) The Theory of Political Coalitions, New Haven: Yale University Press.

Rose, R. (1984) Do Parties Make a Difference?, London: Chatham House.

Strøm, K. and Müller, W.C. (eds.) (forthcoming) Cabinets and Coalition Bargaining: The Democratic Life Cycle in Western Europe, Oxford: Oxford University Press.

Strøm, K., Müller, W.C. and Bergman, T. (eds.) (2003) Delegation and Accountability in Parliamentary Democracies, Oxford: Oxford University Press.

Van Schendelen, M.P.C.M. (1976) 'De troonredes van 1969 tot 1975: wat is gepresteerd?', Beleid \& Maatschappij 3(9): 224-234.

Warwick, P.V. (1994) Government Survival in Parliamentary Democracies, Cambridge: Cambridge University Press.

Weaver, R.K. and Rockman, B.R. (eds.) (1993) Do Institutions Matter? Government Capabilities in The United States and Abroad, Washington, DC: Brookings Institution. 


\section{Notes}

1 We thank Marcel Hanegraaff, Nanette Kistemaker, and Judith van Krieken for their accurate coding of the Queen's speeches, Josta de Hoog for her research assistance, and two anonymous reviewers for their useful suggestions. We also thank the Keesings Historisch Archief for allowing us to use their electronic database of the Queen's speeches. An earlier version of this paper was presented at the Meeting of the American Political Science Association, Chicago, September 2007. We also acknowledge the financial support from Campus The Hague, the Environmental Assessment Agency (MNP) and the Dutch Ministry of Internal Affairs.

2 Oversized refers to the more than simple majority status of governments, also called nonminimal winning coalitions. Government architects do this for strategic reasons - large size reduces vulnerability to weakening parliamentary support.

3 In these and the following figures, we fit simple polynomial regressions as a descriptive exercise, albeit theoretically naive. The choice among alternative polynomial orders was based, since we are working with population data, on degree of obviously discernible change in the resulting lines of best fit.

4 This specific test was suggested by Jennings' analysis of British Queen's speeches, although it entails losing some cases. That is, in addition to the loss of the 1945 values common to all of the tests based on differences, we cannot calculate proportional change when attention increases from zero to some positive number; you cannot divide by zero. This is likely to bias out results against finding evidence of kurtosis since such cases clearly represent punctuation in the sense of attention to a new issue (Jennings and John, 2007).

5 These figures report proportions rather than actual numbers of statements to control for the growing length of speeches. Similar analyses of raw numbers of statements, however, produce essentially identical results. Still, when proportions are examined rather than raw numbers, those with declining numbers of statements seem to decline even more so, while those with increasing numbers appear to increase in proportional terms somewhat less.

6 This is reflected in the third-order polynomial regression result reported in the figure.

7 In both cases, a second-order polynomial provided the best fit, indicating that the trend in attention is still upward.

8 This pattern fits the idea that one cause of the Dutch public crisis on Europe is that Europe was neglected in discussions on domestic policy even though Europe influenced domestic policy, thereby creating a gap between rhetoric and reality of public policy.

9 See, for example, saliency theory dealing with party competition (Budge and Farlie, 1984). See also Rose (1984) on how parties make a difference.

$10 \mathrm{We}$ did not generate a coefficient for outgoing governments, but a look at Figure 8 shows that years in which the Queen's speech was made by a government with caretaker status (e.g., 1972, $1982,1989,2006)$ were not clearly or even not at all years of the highest attention continuity. Such continuity would be expected because of the unwritten institutional rule that caretaker governments refrain from addressing new political topics. We already noted that outgoing governments show relatively low proportions of substantive intentions. But it also may be that these caretaker governments in their speech suspended attention to issues of political controversy, and that this is actually the observed shift in attention - a case of negative agenda-setting.

11 Written coalition agreements appear since the mid-1960s. Since 1967, government breakdowns always led to new elections. Before 1967, a new government sometimes was built after a political crisis without holding early elections, but this procedure came to be seen as a violation of democratic principles.

12 This delegation metaphor forms the basis of Strøm et al.'s (2003) comparative parliamentary research. 


\section{Appendix: The Major Topic Codes}

1. Macro-economie en belastingen (Macro-economics and taxes)

2. Burgerrechten, immigratie en integratie (Civil rights, immigration, and integration)

3. Gezondheid (Healthcare)

4. Landbouw en Visserij (Agriculture and fisheries)

5. Arbeid (Labour)

6. Onderwijs en cultuur (Education and culture)

7. Milieu (Environment)

8. Energiebeleid (Energy)

10. Verkeer en vervoer (Traffic and transport)

12. Justitie, rechtspraak, criminaliteit (Law, court rulings, crime)

13. Sociale zaken (Social affairs)

14. Huisvestingsbeleid en stadsontwikkeling (Housing and city planning)

15. Ondernemingen, binnenlandse handel en commercie (Enterprises, national trade and commerce)

16. Defensie (Defence)

17. Wetenschappelijk onderzoek, technologie en communicatie (Scientific research, technology, and communication)

18. Buitenlandse handel (International trade)

19. Buitenlandse zaken en ontwikkelingssamenwerking (Foreign affairs and foreign aid)

20. Functioneren democratie en openbaar bestuur (Democracy and government)

21. Ruimtelijke ordening, publiek natuur- en waterbeheer (Spatial planning, public nature and water conservation) 